\title{
SYNTHESIS AND ANTIMICROBIAL ACTIVITY OF S-SUBSTITUTED DERIVATIVES OF 1,2,4-TRIAZOL-3-THIOL
}

\author{
Yevhen Karpun, Nataliia Polishchuk
}

The aim of the work. 1,2,4-triazole derivatives possess a wide range of pharmacological activity, so they are used for the development of drugs and active pharmaceutical ingredients. Due to the reactivity of 1,2,4-triazoles there are many options for their further structural modification on different reaction centers. Therefore, the aim of the work was to obtain new S-substituted derivatives of 1,2,4-triazole-3-thiols, study physicochemical parameters of the substances synthesized, evaluate the antimicrobial activity of new S-derivatives of the 4-R ${ }^{1}-5-((3-($ pyridin-4-yl)-1H-1,2,4-triazol-5yl)thio)methyl)-4H-1,2,4-triazole-3-thiol series, and study some regularities of the "structure - biological activity" relationship for the synthesized compounds as well.

Materials and methods. The subject of the study was new S-substituted 1,2,4-triazoles containing 2-oxopropan-1-yl and 2-aryl-2-oxoethan-1-yl substituents. The antimicrobial activity was studied by double serial dilutions on test cultures of Staphylococcus aureus (ATCC 25923), Escherichia coli (ATCC 25922), Pseudomonas aeruginosa (ATCC 27853), and Candida albicans (ATCC 885-653).

The results of the biological screening showed that at a concentration of $125 \mathrm{~g} / \mathrm{mL}$, all synthesized substances showed activity (MIC - in the range of $31.25-62.5 \mu \mathrm{g} / \mathrm{mL}, \mathrm{MBCK}$ - in the range of $62.5-125 \mu \mathrm{g} / \mathrm{mL}$ ) against strains of Escherichia coli, Staphylococcus aureus, Pseudomonas aeruginosa, Candida albicans. Variation of substituents on the sulfur atom did not lead to a significant change in antimicrobial and antifungal activities among derivatives of 4- $R^{I}-5-((3-$ (pyridin-4-yl)-1H-1,2,4-triazole-5-yl) thio)methyl)-4H-1,2,4-triazole-3-thiols.

Conclusions. Biological screening data indicate the prospects for the search for new antimicrobial substances among the abovementioned derivatives of 1,2,4-triazoles. The most active compounds were 1-((4-ethyl-5-((3-(pyridin-4-yl)-1H-1,2,4triazol-5-yl)thio)methyl)-4H-1,2,4-triazol-3-yl)thio)propan-2-one and 1-(4-methoxyphenyl)-2-(4-ethyl-5-(((3-(pyridin-4-yl)1H)-1,2,4-triazol-5-yl)thio)methyl)-4H-1,2,4-triazol-3-yl)thio)ethanone, which showed the most pronounced antimicrobial activity against the Pseudomonas aeruginosa strain (MIC-31.25 $\mathrm{g} / \mathrm{mL}, \mathrm{MBcK}-62.5 \mu \mathrm{g} / \mathrm{mL}$ )

Key words: 1,2,4-triazole, antibacterial activity, antifungal activity

How to cite:

Karpun, Ye., Polishchuk, N. (2021). Synthesis and antimicrobial activity of s-substituted derivatives of 1,2,4-triazol-3-thiol. ScienceRise: Pharmaceutical Science, 3 (31), 64-69. doi: http://doi.org/10.15587/2519-4852.2021.235976

(C) The Author(s) 2021

This is an open access article under the Creative Commons CC BY license

\section{Introduction}

Numerous new strains of microorganisms resistant to antimicrobial drugs have recently been identified all over the globe, creating a serious public health threat [1]. Improvement of the existing and development of new effective antimicrobial and antifungal synthetic medicines is one of the priorities of modern pharmaceutic industry.

1,2,4-triazoles are of a great interest due to being an inexhaustible source for search and development of chemical compounds with a variety of biological activities $[1,2]$. Derivatives of 1,2,4-triazole possess a relatively low toxicity, have a wide spectrum of biological activity and, at the same time, are rather reactive [3, 4]. A high probability of finding a pharmacologically valuable substances among 1,2,4-triazoles and the broad possibilities for their chemical modifications are a solid foundation for the search for new synthetic drugs among them $[5,6]$. Compounds containing 1,2,4-triazole moiety have been demonstrated to have antimicrobial, antitumor, analgesic, hypolipidemic, neuroleptic and other kinds of activities [7-12]. Hence, the synthesis of new highly effective antimicrobial medicines containing this heterocyclic fragment is a promising branch in pharmaceutical chemistry investigations.

The aim. To synthesize new S-substituted derivatives of 1,2,4-triazole-3-thiols, study physicochemical parameters of the substances synthesized, evaluate the antimicrobial activity of new S-derivatives of the 4-R ${ }^{1}-5$ ((3-(pyridin-4-yl)-1H-1,2,4-triazol-5-yl)thio)methyl)-4H1,2,4-triazole-3-thiol series, and study some regularities of the "structure - biological activity" relationship for the synthesized compounds as well.

\section{Planning (methodology) of the research}

To achieve the aim the design of the experiment was done (Fig. 1). 


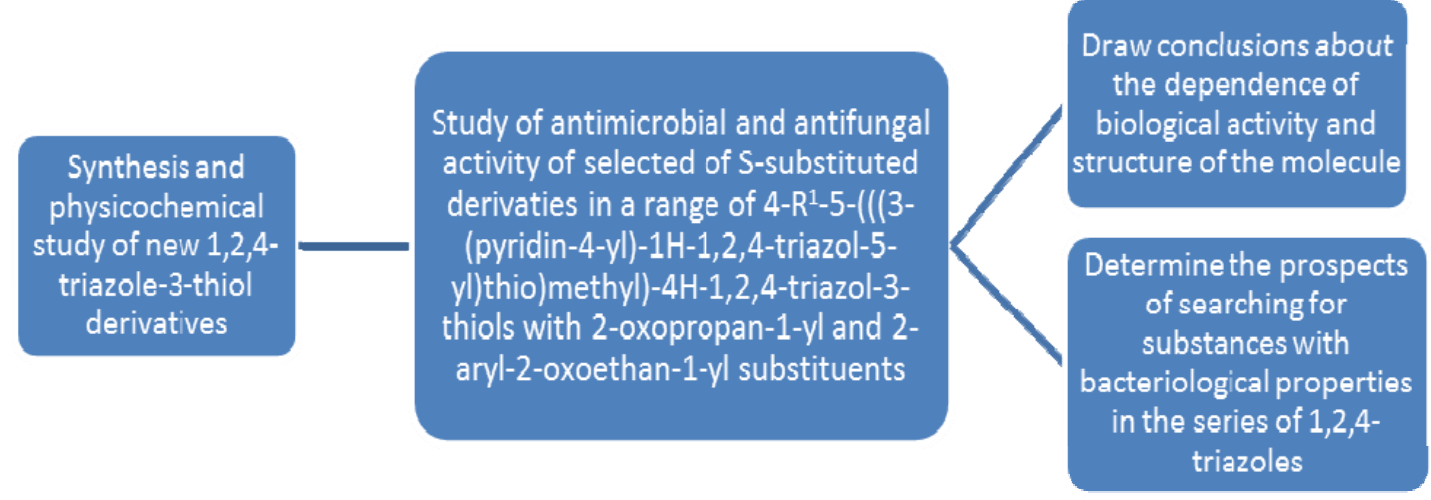

Fig. 1. Algorithm of the research

\section{Materials and methods}

The identity of $S$-substituted derivatives of 1,2,4triazole 3a-3f, 4a-4f has been confirmed by gas chromatography via Agilent 7890B GC system connected with Agilent 5977B mass spectrometry detector (USA). The column used for separation was DB-5ms with the following dimensions: $30 \mathrm{~m} \times 250 \mu \mathrm{m} \times 0.25 \mu \mathrm{m}$. Carrier gas (helium) flow rate was $2.0 \mathrm{~mL} / \mathrm{min}$. Injection volume: $0.5 \mu \mathrm{L}$. Flow split was 1:20. Temperature of the injection system was programmed as follows: $300{ }^{\circ} \mathrm{C} \rightarrow$ $\rightarrow 10{ }^{\circ} \mathrm{C} / \mathrm{s} \rightarrow 310^{\circ} \mathrm{C}$. Oven temperature: programmable, with the initial temperature of $130^{\circ} \mathrm{C}$ ( 1 minute delay) $\rightarrow$ $\rightarrow 20{ }^{\circ} \mathrm{C} / \mathrm{min} \rightarrow 250{ }^{\circ} \mathrm{C}$ (5 min delay). Total time of chromatographic run was $12 \mathrm{~min}$. The temperature of the GC-MS interface was maintained at $280^{\circ} \mathrm{C}$; ion source temperature was $230{ }^{\circ} \mathrm{C}$; temperature of quadrupole mass analyzer was $150^{\circ} \mathrm{C}$. Type of ionization: electron impact (EI) with electron energy of $70 \mathrm{eV}$. Range of scanned mass ratios: $50-500 \mathrm{~m} / \mathrm{z}$.

Melting points were determined according to open capillary method using OptiMelt MPA100 apparatus (USA) equipped with platinum RTD sensor and temperature measurement possibility of up to $400^{\circ} \mathrm{C}$ and $0.1^{\circ} \mathrm{C}$ resolution.

Elemental analysis of the synthesized compounds was afforded using Elementar Vario L cube multipurpose elemental analyzer (CHNS) produced by Analysen systeme $\mathrm{GmbH}$ (Germany) using sulfanilamide as the standard.

${ }^{1} \mathrm{H}$ NMR spectra were recorded on Varian MR-400 spectrometer operating at $400 \mathrm{MHz}$ frequency using DMSO- $d_{6}$ as a solvent and tetramethylsilane (TMS) as an internal standard. Spectra were processed via ADVASPтм Analyzer software (Umatek International Inc.). Chemical shifts are reported in ppm ( $\delta$ scale) downfield with the residual protons of the solvent (DMSO- $d_{6}$ ) observed at $\delta=2.49 \mathrm{ppm}$.
Starting compounds 1, 2 (Scheme 1) are crystalline substances of white colour, insoluble in water and soluble in N,N-dimethylformamide, dimethyl sulfoxide. For analytical purposes, the compounds were recrystallized from water-methanol mixture. The synthesis of the starting thiols 1, 2 have been previously described by other authors [13].

The subject of the research was represented by Ssubstitute derivatives of $4-\mathrm{R}^{1}-5-((3-($ pyridin-4-yl)- $1 H$ 1,2,4-triazole-5-yl)thio)methyl)-4H-1,2,4-triazole-3-

thiols, where whether methyl or ethyl substituents were attached to the position 4 of the triazole ring (Scheme 1).

The compounds 1, 2, 3a-f, 4a-f were synthesized on the Department of Natural Sciences for Foreign Students and Toxicological Chemistry of Zaporizhzhia State Medical University, according to a known procedure [12]; the compounds were further used in the investigation of their antimicrobial activity $[14,15]$.

In the literature tautomeric equilibrium of 1,2,4triazole derivatives was reported $[16,17]$. Thione form is usually dominant in neutral and acidic media, whereas in an alkaline solution the equilibrium is shifted towards the formation of thiol form which can easily react with alkyl halides.

General procedure for the synthesis of $4-R^{1}-5$ ((3-(pyridin-4-yl)-1H-1,2,4-triazole-5-yl)thio)methyl)4H-1,2,4-triazole-3-thiol derivatives

A mixture of sodium hydroxide $(0.01 \mathrm{~mol}, 0.40 \mathrm{~g})$ and a starting 4-alkyl-5-(((3-(pyridin-4-yl)-1H-1,2,4triazol-5-yl)thio)methyl)-4H-1,2,4-triazole-3-thiols $\mathbf{1}, 2$ $(0.01 \mathrm{~mol}, 3.05 / 3.19 \mathrm{~g})$ in methanol was heated until the solid was dissolved, after which one of the alkylating agents (1-bromopropan-2-one, 2-bromo-1-arylethanone) (0.01 mol) was added. After cooling, the precipitate was filtered, dried, and recrystallized from a water-methanol mixture (1:1) (Fig. 1). 

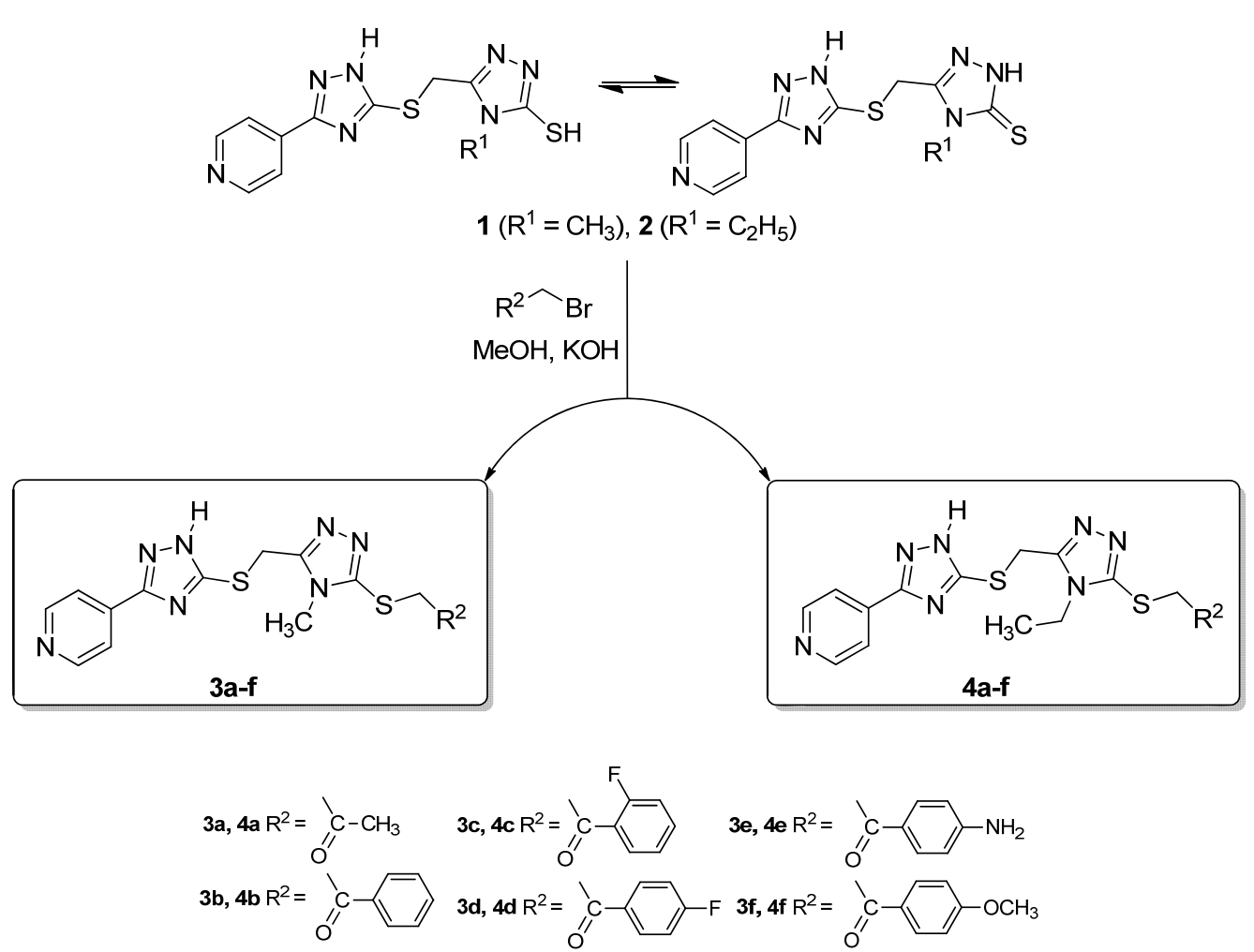

Fig. 1. Synthesis of new 4-R ${ }^{1}-5-(((3-($ pyridin-4-yl)-1H-1,2,4-triazole-5-yl)thio)methyl)-4H-1,2,4-triazol-3-thiol derivatives

\section{Experimental biological part}

Antibacterial and antifungal activities were studied on the Department of Microbiology, Virology and Immunology of ZSMU. ATCC 25923 strain of Staphylococcus aureus, ATCC 25922 strain of Escherichia coli, ATCC 27853 strain of Pseudomonas aeruginosa, and ATCC 885653 strain of Candida albicans were used as the test cultures. The activities were investigated according to the methodological recommendations [9] using a double serial dilutions method in a liquid nutrient medium considered optimal for the test cultures' growth at the concentration of $10^{6}$ cells $/ \mathrm{mL}$. The evaluated compounds were dissolved in dimethyl sulfoxide $(1 \mathrm{mg} / \mathrm{mL})$ prior to the experiment. A minimum inhibitory concentration (MIC) was determined by the absence of a visible growth in a test tube at the minimum concentration of the studied substance sample.
Minimum bactericidal or fungicidal concentrations were determined by seeding the contents of the wells of the plate with dilutions on appropriate dense nutrient media (for bacteria - meat-peptone agar, for yeast-like fungi - dense Saburo medium), and then incubated in the thermostat at the optimal temperature for fungi $\left(37^{\circ} \mathrm{C}\right)$ and bacteria $\left(28^{\circ} \mathrm{C}\right)$ growth. Additionally, control tests of growth media and the solvent were performed in accordance with the known procedures [18].

\section{Results}

The results of the studies on antibacterial and antifungal activities of S-substituted derivatives of 1,2,4triazole with regard to the test cultures are presented in the Table 1. Chlorohexidine was used as a reference antimicrobial drug.

Table 1

The results of antibacterial and antifungal activity studies of the new S-substituted derivatives of 1,2,4-triazole

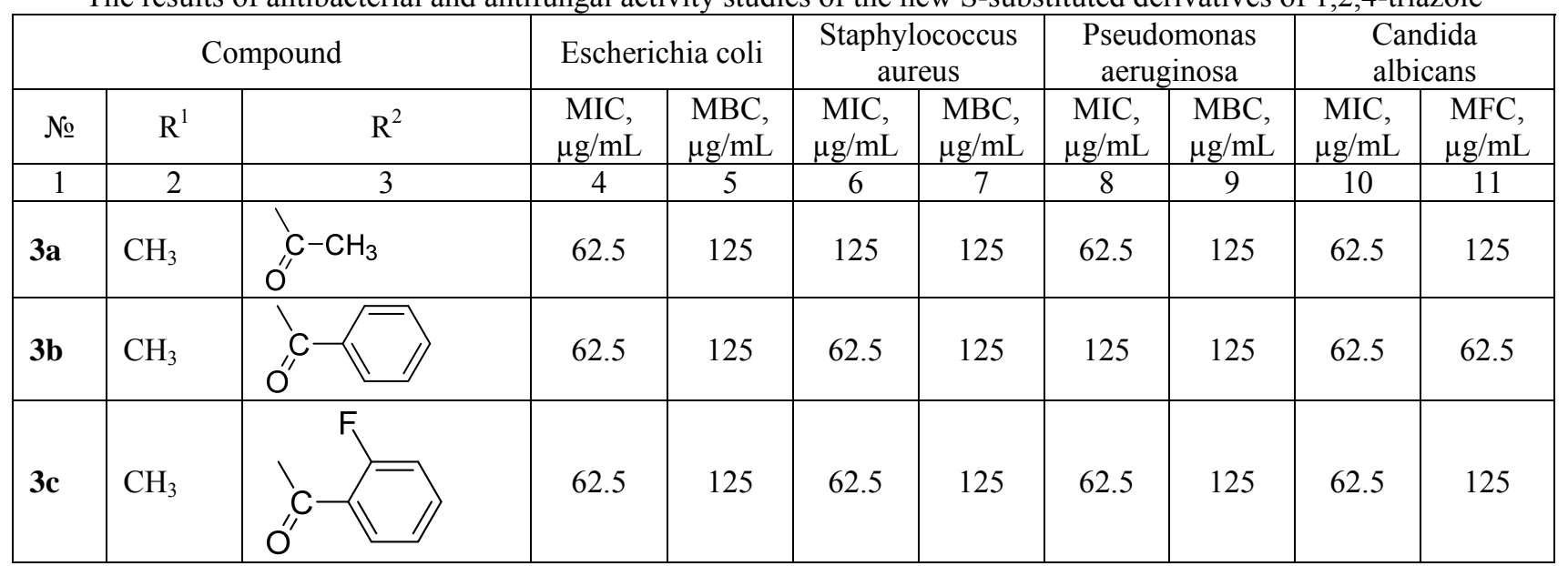


Continuation of Table

\begin{tabular}{|c|c|c|c|c|c|c|c|c|c|c|}
\hline 1 & 2 & 3 & 4 & 5 & 6 & 7 & 8 & 9 & 10 & 11 \\
\hline 3d & $\mathrm{CH}_{3}$ & & 62.5 & 125 & 125 & 125 & 62.5 & 125 & 62.5 & 62.5 \\
\hline $3 \mathbf{e}$ & $\mathrm{CH}_{3}$ & & 62.5 & 125 & 125 & 125 & 62.5 & 125 & 62.5 & 62.5 \\
\hline $3 f$ & $\mathrm{CH}_{3}$ & & 62.5 & 125 & 62.5 & 125 & 62.5 & 125 & 62.5 & 125 \\
\hline $4 a$ & $\mathrm{C}_{2} \mathrm{H}_{5}$ & & 62.5 & 125 & 62.5 & 125 & 31.25 & 62.5 & 62.5 & 125 \\
\hline $4 b$ & $\mathrm{C}_{2} \mathrm{H}_{5}$ & & 62.5 & 125 & 62.5 & 125 & 62.5 & 125 & 62.5 & 62.5 \\
\hline 4c & $\mathrm{C}_{2} \mathrm{H}_{5}$ & & 62.5 & 125 & 125 & 125 & 62.5 & 125 & 62.5 & 62.5 \\
\hline $4 d$ & $\mathrm{C}_{2} \mathrm{H}_{5}$ & & 62.5 & 125 & 62.5 & 125 & 125 & 125 & 62.5 & 62.5 \\
\hline $4 e$ & $\mathrm{C}_{2} \mathrm{H}_{5}$ & & 62.5 & 125 & 125 & 125 & 62.5 & 125 & 62.5 & 62.5 \\
\hline $4 f$ & $\mathrm{C}_{2} \mathrm{H}_{5}$ & & 62.5 & 125 & 125 & 125 & 31.25 & 62.5 & 62.5 & 125 \\
\hline \multicolumn{3}{|c|}{ Chlorohexidine } & - & 25 & - & 18.6 & - & 200 & - & 10.2 \\
\hline \multicolumn{3}{|c|}{ Control solution } & 2500 & 5000 & 2500 & 5000 & 2500 & 5000 & 2500 & 5000 \\
\hline
\end{tabular}

1-((4-Methyl-5-(((3-(pyridin-4-yl)-1H-1,2,4-triazol-5yl)thio)methyl)-4H-1,2,4-triazol-3-yl)thio)propan-2-one (3a). Brown powder in $75 \%$ yield, m.p. $175-177{ }^{\circ} \mathrm{C},{ }^{1} \mathrm{H}$ NMR $\delta$ ppm $2.21(\mathrm{~s}, 3 \mathrm{H}) 3.64(\mathrm{~s}, 3 \mathrm{H}) 3.73(\mathrm{~s}, 2 \mathrm{H}) 5.26(\mathrm{~s}, 2 \mathrm{H}) 7.82$ (d, $J=5.19 \mathrm{~Hz}, 2 \mathrm{H}) 8.56(\mathrm{~d}, J=5.19 \mathrm{~Hz}, 2 \mathrm{H}) \mathrm{MS}(\mathrm{m} / \mathrm{z}): 361$ $\left(\mathrm{M}^{+}\right)$, Calc. for $\mathrm{C}_{14} \mathrm{H}_{15} \mathrm{~N}_{7} \mathrm{OS}_{2}$ : C, 46.52; H, 4.18; N, 27.13, S, $17.74 \%$. Found: C, 46.59; H, 4.21; N, 27.05, S, $17.70 \%$.

1-((4-Ethyl-5-(((3-(pyridin-4-yl)-1H-1,2,4-triazol-5yl)thio)methyl)-4H-1,2,4-triazol-3-yl)thio)propan-2-one (4a). Brown powder in $77 \%$ yield, m.p. $198-200{ }^{\circ} \mathrm{C},{ }^{1} \mathrm{H}$ NMR $\delta$ $1.36(\mathrm{t}, J=6.2 \mathrm{~Hz}, 3 \mathrm{H}) 2.21(\mathrm{~s}, 3 \mathrm{H}) 4.04-4.21$ (m, 4H) 5.27 (s, 2H) $7.81(\mathrm{~d}, J=5.49 \mathrm{~Hz}, 2 \mathrm{H}) 8.49$ (d, $J=5.49 \mathrm{~Hz}, 2 \mathrm{H})$, MS (m/z): $375\left(\mathrm{M}^{+}\right)$. Calc. for $\mathrm{C}_{15} \mathrm{H}_{17} \mathrm{~N}_{7} \mathrm{OS}_{2}$ : C, 47.98; $\mathrm{H}$, 4.56; N, 26.11, S 17.08 \%. Found: C, 47.97; H, 4.52; N, $26.08, \mathrm{~S} 17.20 \%$.

2-((4-Methyl-5-(((3-(pyridin-4-yl)-1H-1,2,4-triazol5-yl)thio)methyl)-4H-1,2,4-triazol-3-yl)thio)-1-phenylethanone (3b). White powder in $79 \%$ yield, m.p. 203-205 ${ }^{\circ} \mathrm{C}$, ${ }^{1} \mathrm{H}$ NMR $\delta$ ppm 3.56 (s, 3H) 4.59 (s, 2H), 4.78 (s, 2H), 7.23$7.27(\mathrm{~m}, 2 \mathrm{H})$ 7.79-7.84 (m, 1H) 8.41-8.46 (m, 4H), 8.73$8.78(\mathrm{~m}, 2 \mathrm{H}), \mathrm{MS}(\mathrm{m} / \mathrm{z}): 423\left(\mathrm{M}^{+}\right)$. Calc. for $\mathrm{C}_{19} \mathrm{H}_{17} \mathrm{~N}_{7} \mathrm{OS}_{2}$ : C, 53.88; H, 4.05; N, 23.15, S $15.14 \%$. Found: C, 53.81; H, $4.06 ; \mathrm{N}, 23.11, \mathrm{~S} 15.22 \%$.

2-((4-Ethyl-5-(((3-(pyridin-4-yl)-1H-1,2,4-triazol-5yl)thio)methyl)-4H-1,2,4-triazol-3-yl)thio)-1-phenylethanone (4b). Yellowish powder in $81 \%$ yield, m.p. $196-198^{\circ} \mathrm{C}$, ${ }^{1} \mathrm{H}$ NMR $\delta$ ppm $1.59(\mathrm{t}, J=5.80 \mathrm{~Hz}, 3 \mathrm{H}) 3.50$ (q, J=6.10 Hz, 2H) 4.57 (s, 2H), 4.77-4.81 (m, 2H) 7.50-7.58 (m, 2H) 7.73$7.77(\mathrm{~m}, 1 \mathrm{H}), 7.85-7.89(\mathrm{~m}, 4 \mathrm{H})$ 8.44-8.48 (m, $2 \mathrm{H}), \mathrm{MS}$ $(\mathrm{m} / \mathrm{z})$ : $437\left(\mathrm{M}^{+}\right)$. Calc. for $\mathrm{C}_{20} \mathrm{H}_{19} \mathrm{~N}_{7} \mathrm{OS}_{2}$ : C, 54.90; H, 4.38;
N, 22.41, S 14.65 \%. Found: C, 54.94; H, 4.30; N, 22.38, S $14.75 \%$.

1-(2-Fluorophenyl)-2-((4-methyl-5-(((3-(pyridin-4yl)-1H-1,2,4-triazol-5-yl)thio)methyl)-4H-1,2,4-triazol-3-yl) thio)ethanone (3c).Yellowish powder in $69 \%$ yield, m.p. 235-237 ${ }^{\circ} \mathrm{C},{ }^{1} \mathrm{H}$ NMR $\delta$ ppm 3.53 (s, 3H) 3.79 (s, 2H) 3.84 $(\mathrm{s}, 2 \mathrm{H}) 7.78(\mathrm{~m}, 2 \mathrm{H})$ 7.80-7.84 (m, 1H) 8.03-8.07 (m, 1H) 8.40-8.45 (m, 2H) 8.64-8.70 (m, 2H). MS (m/z): $441\left(\mathrm{M}^{+}\right)$ Calc. for $\mathrm{C}_{19} \mathrm{H}_{16} \mathrm{FN}_{7} \mathrm{OS}_{2}$ : C, 51.69; H, 3.65; N, 22.21, S 14.52. Found: C, 51.63; H, 3.69; N, 22.15, S $14.63 \%$

1-(2-Fluorophenyl)-2-((4-ethyl-5-(((3-(pyridin-4yl)-1H-1,2,4-triazol-5-yl)thio)methyl)-4H-1,2,4-triazol-3$y$ l) thio)ethanone (4c). Yellowish powder in $79 \%$ yield, m.p. $209-211{ }^{\circ} \mathrm{C},{ }^{1} \mathrm{H}$ NMR $\delta$ ppm 1.73 (t, $\left.J=5.49 \mathrm{~Hz}, 3 \mathrm{H}\right)$ 2.32-2.45 (m, 2H), $4.87(\mathrm{~s}, 2 \mathrm{H}) 6.24(\mathrm{~s}, 2 \mathrm{H})$ 6.80-6.85 $(\mathrm{m}, 2 \mathrm{H}) 7.60-7.65(\mathrm{~m}, 1 \mathrm{H})$ 7.84-7.88 (m, 1H) 7.91-7.95 $(\mathrm{m}, 2 \mathrm{H}) 8.50-8.58(\mathrm{~m}, 2 \mathrm{H}), \mathrm{MS}(\mathrm{m} / \mathrm{z}): 455\left(\mathrm{M}^{+}\right)$. Calc. for $\mathrm{C}_{20} \mathrm{H}_{18} \mathrm{FN}_{7} \mathrm{OS}_{2}$ : C, 52.73; H, 3.98; N, 21.52, S 14.08 \%. Found: C, 52.61; H, 3.96; N, 21.46, S $14.19 \%$

1-(4-Fluorophenyl)-2-((4-methyl-5-(((3-(pyridin-4yl)-1H-1,2,4-triazol-5-yl)thio)methyl)-4H-1,2,4-triazol-3-yl) thio)ethanone (3d). Yellowish powder in $75 \%$ yield, m.p. 195-197 ${ }^{\circ} \mathrm{C},{ }^{1} \mathrm{H}$ NMR $\delta$ ppm $3.66(\mathrm{~s}, 3 \mathrm{H}) 3.71$ (s, 2H) 4.27 $(\mathrm{s}, 2 \mathrm{H}) 7.78-7.82(\mathrm{~m}, 2 \mathrm{H})$ 7.90-7.94 (m, 2H) 8.39-8.45 (m, $2 \mathrm{H})$ 8.58-8.62 (m, $2 \mathrm{H})$, MS $(\mathrm{m} / \mathrm{z}): 441\left(\mathrm{M}^{+}\right)$. Calc. for $\mathrm{C}_{19} \mathrm{H}_{16} \mathrm{FN}_{7} \mathrm{OS}_{2}$ : C, 51.69; H, 3.65; N, 22.21, S $14.52 \%$. Found: C, 51.64; H, 3.62; N, 22.25, S $14.64 \%$.

1-(4-Fluorophenyl)-2-((4-ethyl-5-(((3-(pyridin-4-yl)1H-1,2,4-triazol-5-yl)thio)methyl)-4H-1,2,4-triazol-3-yl)thio) ethanone (4d). Yellowish powder in $81 \%$ yield, m.p. 
165-167 ${ }^{\circ} \mathrm{C},{ }^{1} \mathrm{H}$ NMR $\delta$ ppm 1.69 (t, $\left.J=6.20 \mathrm{~Hz} 3 \mathrm{H}\right) 4.09$ (q, J=6.10 Hz, 2H) 4.29 (s, 2H) 4.80 (s, 2H) 7.33-7.38 (m, 2H), 7.81-7.85 (m, 2H) 8.04-8.09 (m, 2H), 8.45-8.54 (m, $2 \mathrm{H}), \mathrm{MS}(\mathrm{m} / \mathrm{z}): 455\left(\mathrm{M}^{+}\right)$. Calc. for $\mathrm{C}_{20} \mathrm{H}_{18} \mathrm{FN}_{7} \mathrm{OS}_{2}: \mathrm{C}, 52.73$; H, 3.98; N, 21.52, S 14.08 \%. Found: C, 52.79; H, 4.00; N, $21.45, \mathrm{~S} 14.03 \%$.

1-(4-Aminophenyl)-2-((4-methyl-5-(((3-(pyridin-4yl)-1H-1,2,4-triazol-5-yl)thio)methyl)-4H-1,2,4-triazol-3-yl) thio)ethanone (3e). White powder in $68 \%$ yield, m.p. 184$186{ }^{\circ} \mathrm{C},{ }^{1} \mathrm{H}$ NMR $\delta$ ppm 3.71-3.76 (m, 3H) $4.23(\mathrm{~s}, 2 \mathrm{H})$ $4.84(\mathrm{~s}, 2 \mathrm{H})$ 7.84-7.89 (m, 2H) 8.25-8.32 (m, 2H) 8.58$8.62(\mathrm{~m}, 2 \mathrm{H})$ 8.74-8.79 (m, 2H), MS (m/z): $438\left(\mathrm{M}^{+}\right)$. Calc. for $\mathrm{C}_{19} \mathrm{H}_{18} \mathrm{~N}_{8} \mathrm{OS}_{2}$ : C, 52.04; H, 4.14; N, 25.55; S, $14.62 \%$. Found: C, 52.15; H, 4.03; N, 25.08, S $14.55 \%$.

1-(4-Aminophenyl)-2-((4-ethyl-5-(((3-(pyridin-4-yl)-

1H-1,2,4-triazol-5-yl)thio)methyl)-4H-1,2,4-triazol-3-yl)thio) ethanone (4e). White powder in $72 \%$ yield, m.p. 153-155 ${ }^{\circ} \mathrm{C},{ }^{1} \mathrm{H}$ NMR $\delta$ ppm 1.85 (t, $J=6.20 \mathrm{~Hz}, 3 \mathrm{H}$ ) 3.70 (q, $J=6.10$ $\mathrm{Hz}, 2 \mathrm{H}) 3.80$ (s, 2H) 4.20 (s, 2H) 7.89-7.83 (m, 2H) 8.228.27 (m, 2H) 8.59-8.63 (m, 2H) $8.74(\mathrm{~d}, J=6.41 \mathrm{~Hz}, 2 \mathrm{H}), \mathrm{MS}$ $(\mathrm{m} / \mathrm{z})$ : $452\left(\mathrm{M}^{+}\right)$. Calc. for $\mathrm{C}_{20} \mathrm{H}_{20} \mathrm{~N}_{8} \mathrm{OS}_{2}$ : C, 53.08; H, 4.45; N, 24.76; S, 14.17 \%. Found: C, 53.00; H, 4.58; N, 24.78, S $14.11 \%$.

1-(4-Methoxyphenyl)-2-((4-methyl-5-(((3-(pyridin-4yl)-1H-1,2,4-triazol-5-yl)thio)methyl)-4H-1,2,4-triazol-3-yl) thio)ethanone (3f). White powder in $73 \%$ yield, m.p. 172$174{ }^{\circ} \mathrm{C},{ }^{1} \mathrm{H}$ NMR $\delta$ ppm 3.55 (s, 3H) 3.85 (s, 3H) 4.15 (s, 2H) $5.89(\mathrm{~s}, 2 \mathrm{H}) 7.09-7.13(\mathrm{~m}, 2 \mathrm{H}) 7.78-7.81(\mathrm{~m}, 2 \mathrm{H})$ 8.008.04 (m, 2H) 8.63-8.67 (m, 2H), MS (m/z): $453\left(\mathrm{M}^{+}\right)$. Calc. for $\mathrm{C}_{20} \mathrm{H}_{19} \mathrm{~N}_{7} \mathrm{O}_{2} \mathrm{~S}_{2}$ : C, 52.97; H, 4.22; N, 21.62; S, $14.14 \%$. Found: C, 52.92; H, 4.20, N, 21.75, S $14.10 \%$.

1-(4-Methoxyphenyl)-2-((4-ethyl-5-(((3-(pyridin-4yl)-1H-1,2,4-triazol-5-yl)thio)methyl)-4H-1,2,4-triazol-3-yl) thio)ethanone (4f). White powder in $82 \%$ yield, m.p. 191$193{ }^{\circ} \mathrm{C},{ }^{1} \mathrm{H}$ NMR $\delta$ ppm 1.76 (t, $\left.J=7.02 \mathrm{~Hz}, 3 \mathrm{H}\right) 3.64$ (s, $3 \mathrm{H}) 3.76$ (q, $J=6.12 \mathrm{~Hz}, 4 \mathrm{H}) 4.14$ (s, 2H) 5.80 (s, 2H) 7.82$7.86(\mathrm{~m}, 2 \mathrm{H}) 8.15-8.19(\mathrm{~m}, 2 \mathrm{H})$ 8.57-8.62 (m, 2H) 8.62-8.66 $(\mathrm{m}, 2 \mathrm{H})$, MS (m/z): 467( $\left.\mathrm{M}^{+}\right)$. Calc. for $\mathrm{C}_{21} \mathrm{H}_{21} \mathrm{~N}_{7} \mathrm{O}_{2} \mathrm{~S}_{2}$ : C, 53.95; H, 4.53; N, 20.97; S, $13.71 \%$. Found: C, 53.98; H, $4.48 ; \mathrm{N}, 21.02 ; \mathrm{S}, 13.74 \%$.

The signals of the NH-protons of triazole fragment and amino groups were not detected in the ${ }^{1} \mathrm{H}$ NMR spectra, probably due to the fast deuteroexchange.

According to the obtained data, all of the Sderivatives of 4-R ${ }^{1}-5-(((3-(p y r i d i n-4-y l)-1 H-1,2,4-t r i a z o l-5-$ yl)thio)methyl)-4H-1,2,4-triazol-3-thiol exhibited mild antimicrobial activity against Escherichia coli, Staphylococcus aureus, Pseudomonas aeruginosa and Candida albicans with MIC values of $62.5 \mu \mathrm{g} / \mathrm{mL}$ and the corresponding MBC of $125 \mu \mathrm{g} / \mathrm{mL}$.

It is worth noting that 1-((4-ethyl-5-(((3-(pyridin-4yl)-1H-1,2,4-triazol-5-yl)thio)methyl)-4H-1,2,4-triazol-3-yl) thio)propan-2-one (4a) and 1-(4-methoxyphenyl)-2-((4ethyl-5-(((3-(pyridin-4-yl)-1H-1,2,4-triazol-5-yl)thio)methyl)-4H-1,2,4-triazol-3-yl)thio)ethanone (4f) expressed a remarkable activity against the test strain of Pseudomonas aeruginosa (MIC $31.25 \mu \mathrm{g} / \mathrm{mL}$; MBC $62.5 \mu \mathrm{g} / \mathrm{mL}$ ). In some cases, the change of $\mathrm{N}$-methyl substituent with $\mathrm{N}$-ethyl one decreased MBC value from $125 \mu \mathrm{g} / \mathrm{mL}$ to $62.5 \mu \mathrm{g} / \mathrm{mL}$.

\section{Discussion}

The investigation of antimicrobial activity of the obtained compounds revealed the fact that at the concentration of $125 \mu \mathrm{g} / \mathrm{mL}$ all of the synthesized compounds were active against the strains of Escherichia coli, Staphylococcus aureus, Pseudomonas aeruginosa, and Candida albicans.

The analysis of the results of studied compounds antibacterial activity allows concluding that the variation of different 2-oxopropan-1-yl and 2-aryl-2-oxoethan-1-yl moieties does not dramatically impact the antimicrobial and antifungal activities of $4-\mathrm{R}^{1}-5-(((3-$ (pyridin-4-yl)-1H-1,2,4triazole-5-yl)thio)methyl)-4H-1,2,4-triazol-3-thiol derivatives. It is worth noting that the derivatives of 1,2,4-triazole used in the research did not significantly differ from each other in terms of growth inhibition of Escherichia coli, Staphylococcus aureus, and Candida albicans strains (MIC values ranged between 62.5 to $125 \mu \mathrm{g} / \mathrm{mL}$; MBC and MFC between 62.5 to $125 \mu \mathrm{g} / \mathrm{mL}$ ).

Study limitations. The serial dilution method is a useful technique in laboratories, but it faces some limitations. Because serial dilution is performed in a stepwise manner, it requires a more extended period. Prepared environments must be deployed immediately, with no storage capability. It is limiting the efficiency of the method.

Prospects for further research. Under these conditions, the fact of finding new promising antimicrobial substances, namely 1-((4-ethyl-5-(((3-(pyridin-4-yl)-1H-1,2,4triazol-5-yl)thio)methyl)-4H-1,2,4-triazol-3-yl)thio)propan2-one (4a) and 1-(4-methoxyphenyl)-2-((4-ethyl-5-(((3(pyridin-4-yl)-1H-1,2,4-triazol-5-yl)thio)methyl)-4H-1,2,4triazol-3-yl)thio)ethanone (4f), is of considerable interest to be used in further search for and development of new antimicrobial drugs of heterocyclic nature. Our further steps will be to study the synthesized compounds for other types of biological activity.

\section{Conclusions}

1. We have developed a simple and efficient method for the synthesis of novel S-substituted derivatives of 1,2,4triazole-3-thiols containing 2-oxopropan-1-yl and 2-aryl-2oxoethan-1-yl substituents. The structure and purity of new 1,2,4-triazoles were confirmed by GC-MS analysis, elemental analysis and ${ }^{1} \mathrm{H}$ NMR spectroscopy method.

2 . The study of S-derivatives of 4-R $\mathrm{R}^{1}-5-(((3-$-(pyridin4-yl)-1H-1,2,4-triazol-5-yl)thio)methyl)-4H-1,2,4-triazol-3thiols showed that the synthesized compounds exhibit antimicrobial and antifungal activities.

3. Compounds 1-((4-ethyl-5-(((3-(pyridin-4-yl)-1H1,2,4-triazol-5-yl)thio)methyl)-4H-1,2,4-triazol-3-yl)thio) propan-2-one (4a) and 1-(4-methoxyphenyl)-2-((4-ethyl-5(((3-(pyridin-4-yl)-1H-1,2,4-triazol-5-yl)thio)methyl)-4H1,2,4-triazol-3-yl)thio)ethenone (4f) possess the most potent antimicrobial activity against the strain of Pseudomonas aeruginosa (MIC of $31.25 \mu \mathrm{g} / \mathrm{mL}, \mathrm{MBC}$ of $62.5 \mu \mathrm{g} / \mathrm{mL}$ ).

4. Certain relationships between the chemical structure and antimicrobial and antifungal activities of the synthesized compounds have been determined. It indicates that the search for compounds expressing bactericidal activity in the studied range of derivatives is relevant for research. 
Conflict of interests interest.

The authors declare that they have no conflicts of

\section{Financing}

The study was performed without financial support.

\section{Acknowledgments}

The authors would like to thank, the late (recently deceased), Professor, Doctor of Pharmaceutical Sciences, Knysh Yevhenii Hryhorovych

\section{References}

1. Serwecińska, L. (2020). Antimicrobials and Antibiotic-Resistant Bacteria: A Risk to the Environment and to Public Health. Water, 12 (12), 3313. doi: http://doi.org/10.3390/w12123313

2. Boraei, A. T. A., El Ashry, E. S. H., Duerkop, A. (2016). Regioselectivity of the alkylation of S-substituted 1,2,4-triazoles with dihaloalkanes. Chemistry Central Journal, 10 (1). doi: http://doi.org/10.1186/s13065-016-0165-0

3. Safonov, A. A. (2018). Study acute toxicity of 4-(R-amino)-5-(thiophen-2-ylmethyl)-4H-1,2,4-triazole-3-thiol in vivo. Farmatsevtychnyi Zhurnal, 2, 98-101. doi: http://doi.org/10.32352/0367-3057.2.16.06

4. Bihdan, O. A., Parchenko, V. V. (2018). Synthesis and physical-chemical properties of some 5-(3-fluorophenyl)-4-methyl1,2,4-triazole-3-thiol derivatives. Farmatsevtychnyi Zhurnal, 2, 38-47. doi: http://doi.org/10.32352/0367-3057.2.17.05

5. Chaudhary, P. M., Tupe, S. G., Jourwekar, S. U. et. al. (2015). Synthesis and antifungal potential of 1,2,3-triazole and 1,2,4-triazole thiol substituted strobilurin derivatives. Indian Journal of Chemistry, 54 B, 908-911.

6. Parchenko, V. V., Parkhomenko, L. I., Izdepskyi, V. Y., Panasenko, O. I., Knysh, Ye. H. (2013). Pharmacological and biochemical characteristics of piperidine 2-(5-furan-2-yl)-4-phenyl-1,2,4-triazol-3-iltioacetate. Zaporozhye Medical Journal, 1, $39-41$.

7. Rao, D. V. N. (2015). Synthesis, Characterization and Antimicrobial Evaluation of Substituted 1,2,4-Triazole Thiones Containing Pyrazole Moiety. Journal of Clinical and Analytical Medicine, 6 (5). doi: http://doi.org/10.4328/jcam.2323

8. Saadeh, H. A., Mosleh, I. M., Al-Bakri, A. G., Mubarak, M. S. (2010). Synthesis and antimicrobial activity of new 1,2,4triazole-3-thiol metronidazole derivatives. Chemical Monthly, 141 (4), 471-478. doi: http://doi.org/10.1007/s00706-010-0281-9

9. Metodychni vkazivky 9.9.5-143-2007 «Vyznachennia chutlyvosti mikroorhanizmiv do antybakterialnykh preparativ» (2007). Kyiv: MOZ Ukrainy, 63.

10. Ding, Y., Zhang, Z., Zhang, G., Mo, S., Li, Q., Zhao, Z. (2015). Green synthesis and evaluation of the antitumor activity of a novel series of 3-[4-bi-(4-fluorophenyl)methylpiperazinyl]-4-amino-5-thione-1,2,4-triazole Schiff bases. Research on Chemical Intermediates, 42 (4), 3105-3116. doi: http://doi.org/10.1007/s11164-015-2200-5

11. Perekhoda, L. A. (2014). Assessment of Quantitative Structure-Anticonvulsive Activity Relationships in a Series of Derivatives of 1,2,3-Triazole $(1 \mathrm{H}), 1,2,4-$ Triazole $(4 \mathrm{H}), 1,3,4-O x a d i a z o l e(1 \mathrm{H})$, and 1,3,4-Thiadiazole $(1 \mathrm{H})$. Pharmaceutical Chemistry Journal, 47 (11), 586-588. doi: http://doi.org/10.1007/s11094-014-1012-Z

12. Gotsulya, A. S., Mikolasyuk, O. O., Panasenko, O. I., Knysh, Ye. G. (2014). Synthesis and investigation of the physicochemical properties of 2-(5-((theophylline-7'-yl)methyl)-4-phenyl-4H-1,2,4-triazole-3-ylthio)-acetic acid salts. Zaporozhye Medical Journal, 1, 91-94. doi: http://doi.org/10.14739/2310-1210.2014.1.23820

13. Volyanskiy, Yu. L., Gritsenko, I. S., Shirobokov, V. P. et. al. (2004). Vivchennya spetsifichnoi aktivnosti protimikrobnikh likarskikh zasobiv. Kyiv: DFTS MOZ Ukraini, 38.

14. Hotsulia, A. S., Knysh, Y. H. (2020). Synthesis, structure and properties of 7-((4-amino-5-thio-1,2,4-triazole-3yl)methyl)-theophylline derivatives. Current Issues in Pharmacy and Medicine: Science and Practice, 13 (2 (33)), 176-184. doi: http://doi.org/10.14739/2409-2932.2020.2.207019

15. Bihdan, O. A., Parchenko, V. V. (2017). Physical-chemical properties of 5-(3-fluorophenyl)-4-amino-1,2,4-triazole-3-thiol sderivatives. Current Issues in Pharmacy and Medicine: Science and Practice, 10 (2 (24)), 135-140. doi: http://doi.org/10.14739/24092932.2017.2.103517

16. Zamani, K., Faghihi, K., Sangi, M. R., Zolgharnein, J. (2003). Synthesis of some new substituted 1,2,4-triazole and 1,3,4thiadiazole and their derivatives. Turkish Journal of Chemistry, 27, 119-125.

17. Davari, M. D., Bahrami, H., Haghighi, Z. Z., Zahedi, M. (2009). Quantum chemical investigation of intramolecular thione-thiol tautomerism of 1,2,4-triazole-3-thione and its disubstituted derivatives. Journal of Molecular Modeling, 16 (5), $841-855$. doi: http://doi.org/10.1007/s00894-009-0585-z

18. Datoussaid, Y., Othman, A., Kirsch, G. (2012). Synthesis and antibacterial activity of some 5,5'-(1,4-phenylene)-bis-1,3,4oxadiazole and bis-1,2,4-triazole derivatives as precursors of new S-nucleosides. South African Journal of Chemistry, 65, 30-35.

Received date 02.02.2021

Accepted date 02.06.2021

Published date 30.06.2021

Yevhen Karpun, Assistant, Department of Natural Sciences for Foreign Students and Toxicological Chemistry, Zaporizhzhia State Medical University, Maiakovskoho ave., 26, Zaporizhzhia, Ukraine, 69035

Nataliia Polishchuk, PhD, Associate Professor, Department of Microbiology, Virology and Immunology, Zaporizhzhia State Medical University, Zaporizhzhia State Medical University, Maiakovskoho ave., 26, Zaporizhzhia, Ukraine, 69035

*Corresponding author: Yevhen Karpun, e-mail: ekarpun@yahoo.com 